Jurnal Pemberdayaan: Publikasi Hasil Pengabdian kepada Masyarakat

Vol. 2, No. 1, April 2018, Hal. 51-58

ISSN: 2088 4559; e-ISSN: XXXX-XXXX

DOI:

\title{
PROGRAM PENINGKATAN KEWIRAUSAHAAN DALAM PEMBERDAYAAN MASYARAKAT RW O5 DEMANGAN, GONDOKUSUMAN, YOGYAKARTA
}

\author{
Liena Sofiana, Siti Nur Khopipah, Yolanda Rachmadita, Arib Cahyo Saputro \\ Universitas Ahmad Dahlan, Jalan Prof. Dr. Soepomo, S.H. Janturan Yogyakarta 55164 \\ Email: liena.sofiana@ikm.uad.ac.id
}

\begin{abstract}
ABSTRAK
Program Peningkatan Kewirausahaan ini merupakan bentuk kegiatan pemberdayaan masyarakat dengan tujuan menciptakan peluang usaha mandiri dengan kemampuan dan kreatifitas dalam kehidupan masyarakat itu sendiri dan tentunya dapat menambah wawasan mengenai proses pembuatan dan manfaat dari produk-produk yang digunakan dan dihasilkan. Metode yang digunakan adalah dengan pelatihan dan praktik pembuatan sabun air cuci piring dan pembuatan batik jumput. Hasil yang diperoleh adalah kegiatan pelatihan berjalan dengan baik dan warga peserta pelatihan aktif bertanya dan mengikuti kegiatan pelatihan sampai selesai. Pelatihan dilakukan dengan interaktif antara narasumber dengan warga peserta pelatihan.
\end{abstract}

Kata kunci: pelatihan, kewirausahaan, produk

\begin{abstract}
This Entrepreneurship Improvement Program is a form of community empowerment activity with the aim of creating independent business opportunities with the ability and creativity in the life of the community it self and of course can add insight into the manufacturing process and the benefits of the products used and produced. The method used is training and practice of making dishwashing water soap and making batik jumput. The results obtained were that the training activities went well and residents of the training participants actively asked questions and attended the training activities to completion. Training is carried out interactively between speakers and community members.
\end{abstract}

Keywords: training, entrepreneurship, product

\section{PENDAHULUAN}

Salah satu masalah yang harus dihadapi oleh negara-negara sedang berkembang adalah banyaknya penduduk yang hidup dalam kemiskinan. Perlu disadari bahwa masalah kemiskinan bukan hanya masalah ekonomi, melainkan merupakan masalah yang kompleks. Salah satu alternative pemecahan adalah melalui kegiatan pemberdayaan, dan pendidikan kewirausahaan, guna mengubah sikap mental ketergantungan serta menumbuhkembangkan etos kerja, sehingga diharapkan dapat menumbuhkan kemandirian (Sukidjo, 2012) .

Karena ketidakmampuan yang terjadi di masyarakat, maka diperlukan terobosan dan pendekatan baru yang salah satu diantaranya adalah pengembangan kewirausahaan untuk meningkatkan ekonomi masyarakat melalui pemberdayaan. Pengembangan kewirausahaan 
masyarakat diharapkan menjadi terobosan baru agar dapat mempercepat pencapaian tumbuhnya wirausaha-wirausaha yang mandiri yang memiliki karakter inovatif, tangguh dan berwawasan global (Malik \& Mulyono, 2017).

Kewirausahaan sebagai kemampuan untuk menciptakan sesuatu yang baru dan berbeda. Kewirausahaan merupakan kemampuan kreatif dan inovatif, mampu melihat peluang dan selalu terbuka untuk setiap masukan dan perubahan yang positif yang mampu membawa bisnis terus bertumbuh serta memiliki nilai. Dengan kegiatan wirausaha diharapkan orangorang mampu mengubah sebuah kesempatan menjadi sebuah usaha yang menghasilkan, yang diolah melalui kreatifitas, inovasi dan keunikan dalam membuat suatu produk. Hal ini bisa dicapai melalui kegiatan bisnis yang dilakukan dengan menerapkan konsep kewirausahaan. Konsep kewirausahaan sosial telah menjadi konsep yang popular di berbagai Negara. Berbagai kalangan mulai memperbincangkan konsep kewirausahaan sosial sebagai solusi inovatif dalam menyelesaikan permasalahan sosial (Saragih, 2017).

Pemberdayaan kepada masyarakat merupakan upaya untuk memulihkan atau meningkatkan keberdayaan suatu komunitas agar mampu berbuat sesuai dengan harkat dan martabat mereka dalam melaksanakan hak-hak dan tanggung jawab mereka sebagai komunitas manusia dan warga negara Selain itu, tujuan pemberdayaan masyarakat sendiri untuk menciptakan perubahan sosial yang berdampak pada daya saing yang diiringi dengan meningkatnya pengetahuan dan kemampuan dalam memenuhi kebutuhan hidup yang lebih baik, dengan kata lain lebih produktif, baik yang bersifat fisik maupun kesejahteraan sosial (Harahap, 2012).

Berbagai program dilakukan sebagai upaya dalam meningkatkan kesejahteraan masyarakat, salah satunya adalah pengembangan wawasan kewirausahaan. Istilah kewirausahaan adalah sebuah proses dalam merubah ide menjadi kesempatan komersil dan menciptakan nilai (harga). Secara singkat John Howkins juga menjelaskan dalam waawancaranya pada World Intellectual Property Organization (WIPO) bahwa kewirausahaan merupakan "Kegiatan ekonomi dalam masyarakat sebagian besar waktunya untuk menghasilkan ide, tidak hanya melakukan hal-hal yang rutin dan berulang. Karena bagi masyarakat ini, menghasilkan ide merupakan hal yang harus dilakukan untuk kemajuan" (Melicher, 2015).

Program peningkatan kewirausahaan ini merupakan salah satu program pemberdayaan masyarakat yang meliputi Pelatihan Pembuatan Sabun Cair Cuci Piring dan Pelatihan Membatik Jumput. Pelatihan semacam ini diselenggarakan agar masyarakat Demangan 
khususnya RW 05 dapat mengetahui, mengenal, dan menjadikan peluang bisnis baru dalam meningkatkan ekonomi kehidupan secara mandiri. Khususnya sabun cuci piring yang memang digunakan dan dibutuhkan dalam kehidupan sehari-hari. Pelatihan Pembuatan Sabun Cair dan Cuci Piring maupun Membatik Jumput ini sendiri dapat dilakukan menggunakan bahan-bahan yang sederhana dan sangat mudah didapatkan. Kegiatan pelatihan dalam mewujudkan ekonomi yang mandiri pada masyarakat ini juga diharapkan dapat meningkatkan kepedulian masyarakat tentang bagaimana pentingnya meningkatkan kesejahteraan kehidupan dalam bidang ekonomi apabila memiliki kemauan dan kemampuan dalam mengembangkan ide dan kreatifitas.

\section{METODE}

Metode pengabdian yang diterapkan adalah dengan menjalankan Program Peningkatan Kewirausahaan, yaitu meliputi pelatihan dan pembuatan sabun cair cuci piring dan pelatihan membatik jumput. Bahan yang digunakan dalam program peningkatan kewirausahaan adalah materi presentasi berupa tujuan, langkah-langkah dan manfaat dari pelatihan dan pembuatan sabun cair cuci piring dan membatik jumput.

Tabel 1. Metode dan Kegiatan Pengabdian

\begin{tabular}{|l|l|l|}
\hline No & Metode Pengabdian & \multicolumn{1}{c|}{ Kegiatan } \\
\hline \multirow{2}{*}{1} & \multirow{2}{*}{ Pelatihan Membatik Jumput } & $\begin{array}{l}\text { Memberikan pengenalan dan penjelasan alat bahan } \\
\text { yang digunakan untuk proses membatik jumput }\end{array}$ \\
\cline { 3 - 3 } & & $\begin{array}{l}\text { Memberikan penjelasan tentang bahan- } \\
\text { bahan yang digunakan dalam membuat } \\
\text { 2abun cair cuci piring }\end{array}$ \\
\hline \multirow{2}{*}{$\begin{array}{l}\text { Pelatihan pembuatan } \\
\text { sabun cair cuci piring }\end{array}$} & $\begin{array}{l}\text { Memberi penjelasan mengenai kegunaan } \\
\text { dan bahan-bahan yang diperlukan untuk } \\
\text { membuat sabun cair cuci piring }\end{array}$ \\
\cline { 3 - 4 } & & Membuat sabun cair cuci Piring \\
\hline
\end{tabular}

\section{HASIL, PEMBAHASAN, DAN DAMPAK}

Budaya kewirausahaan perlu diperkenalkan ketengah masyarakat sedini mungkin dimulai dari lingkungan yang terdekat yaitu keluarga. Pengembangan program kewirausahaan harus dilakukan secara terintegrasi (terpadu) secara berkelnjutan dan bukan hanya secara 
persial saja. Hal ini dilakukan mulai dari tingkat struktur yang terendah seperti melibatkan RT/RW, kelurahan dan seterusnya (Jonnius, 2013).

Pelatihan Pembuatan Sabun Cair Cuci Piring dan Pelatihan Membatik Jumput dilaksanakan di hari, tanggal, dan waktu yang berbeda. Pertama adalah Pelatihan Pembuatan Sabun Cair Cuci Piring yang diselenggarakan pada bulan November dan yang kedua adalah Pelatihan Membatik Jumput yang diselenggarakan pada bulan Desember. Kedua program ini dilakukan di lokasi yang berbeda, yaitu Balai Pertemuan Kantor Kelurahan untuk pelatihan sabun dan Rumah Warga untuk pelatihan membatik.

1. Pelatihan Pembuatan Sabun Cair Cuci Piring

Sabun Cair Cuci Piring merupakan salah satu bahan kebutuhan rumah tangga yang sangat penting dan pokok dalam kehidupan. Sabun digunakan untuk mendapatkan standar kebersihan yang baik, khususnya sabun cuci piring yang diaplikasikan pada piring dan alat rumah tangga lainnya. Pembuatan sabun cuci piring secara massal semacam ini mampu membantu mengurangi pengeluaran masyarakat untuk pembelian sabun dengan harga yang mahal (Amalia dkk., 2018). Bahan yang digunakan antara lain, texapon sebagai penghasil busa, comperland sebagai anti bakteri, sodium sulfat sebagai pengawet, aquades sebagai pelarut, asam sitris sebagai pengangkat lemak, parfum, propilen glikol sebagai pengikat parfum, pewarna, dan EDTA sebagai pengawet. Sedangkan alat yang digunakan hanya berupa ember, sotil atau pengaduk kayu, corong, dan botol kemasan.
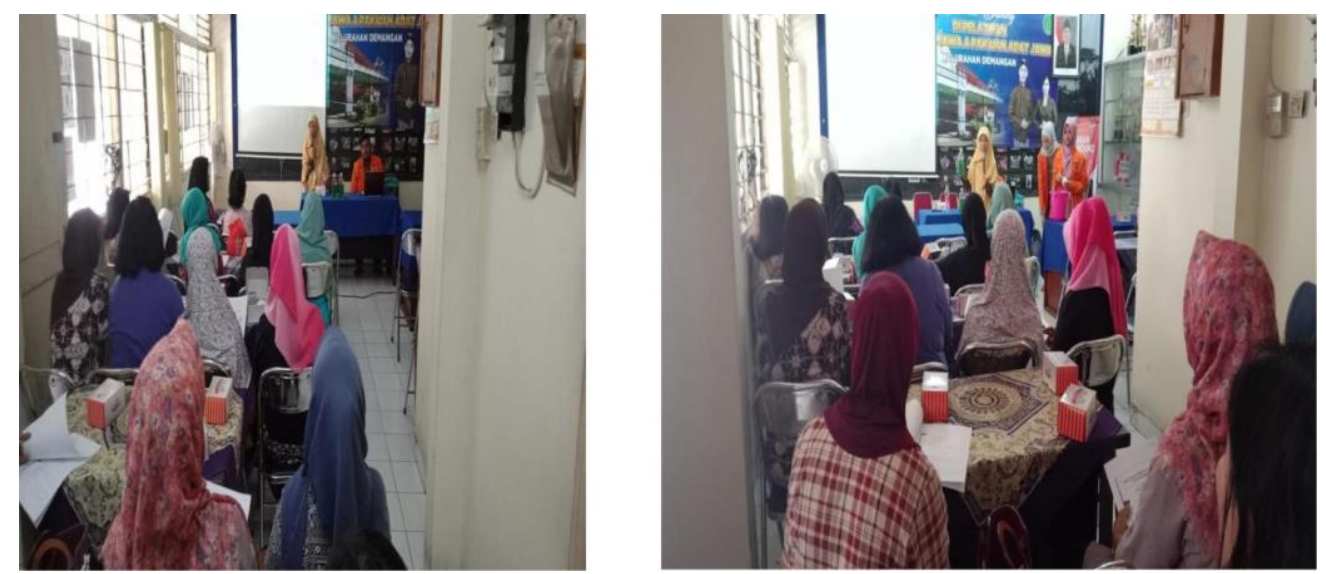

Gambar 1 Penyampaian Materi Pelatihan Sabun Cair Cuci Piring

Pelatihan pembuatan sabun cair ini dihadiri oleh masyarakat RW 05 yang berjumlah sebanyak 40 orang. Tahap pertama yang dilakukan adalah pengenalan alat dan bahan yang digunakan dan disampaikan oleh Pemateri, tahap kedua sesi tanya-jawab 
tentang kegunaan masing-masing bahan yang digunakan, dan tahap terakhir adalah praktik pembuatannya.

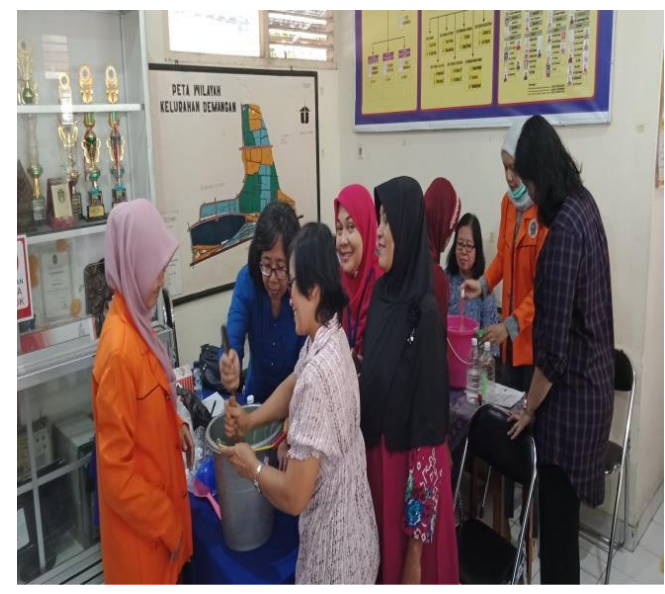

\section{Gambar 3 Praktik Pembuatan Sabun}

Suasana selama praktik pembuatan sabun yang melibatkan warga Dusun Demangan. Diharapkan dengan adanya kegiatan pelatihan ini dapat meningkatkan pengetahuan dan keterampilan dalam berwirausaha.

Praktik pembuatan

2. Pelatihan Membatik Jumput

Kegiatan Kewirausahaan di tingkat RT/RW misalnya membuat kerajinan masyarakat dengan mengangkat tradisi masyarakat tempatan yang dapat dijadikan sebagai sebuah kegiatan bisnis misalya dengan dengan usaha batik tangan buatan mereka (Jonnius, 2013). Membatik merupakan salah satu kegiatan yang bermanfaat untuk meneruskan warisan budaya Indonesia. Saat ini pemakaian batik sudah terkenal di mancanegara dan eksistensi nya tidak kalah dengan model pakaian modern. Di zaman yang serba modern ini, pembuatan batik mengalami perubahan perkembangan, beberapa produksi masih menerapkan batik dengan cara tradisional dan adapula yang sudah memakai cara yang lebih modern dan praktis, salah satunya yaitu batik jumputan.

Batik jumputan adalah salah satu jenis batik yang menggunakan teknik jumputan untuk membuat motifnya. Jumputan sendiri adalah salah satu teknik yang digunakan untuk membuat motif batik dengan cara mengikat kencang beberapa bagian kain yang kemudian dicelupkan pada pewarna pakaian (Ningsih, 2001). Batik jumputan juga sering disebut dengan batik ikat celup karena proes pembuatannya dengan mengikat dan mencelupkan kain kedalam pewarna. 

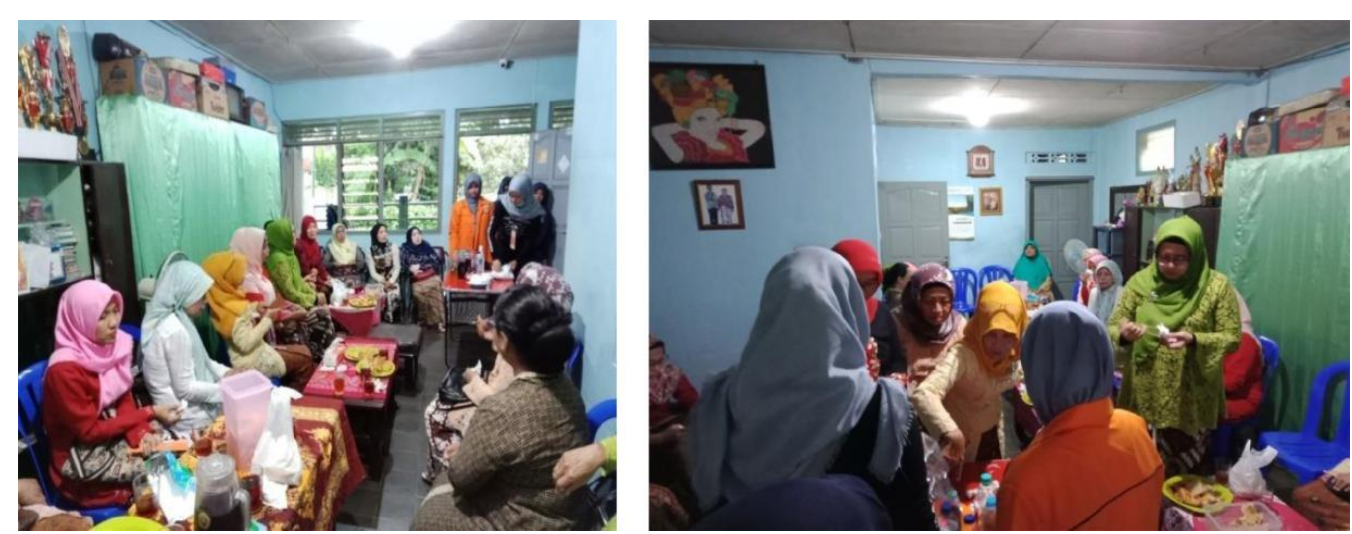

Gambar 3 Pengenalan Alat dan Bahan dan Praktik Membatik Jumput

Bahan-bahan membatik berupa kain, pewarna pakaian, asam cuka (sebagai pengikat warna), dan air (sebagai pelarut). Alat yang digunakan juga sangat mudah yaitu piring/tatakan, botol akua, dan karet gelang (sebagai pengikat). Pelatihan ini dihadiri oleh ibu-ibu RT 17 Demangan yang berjumlah sekitar 30 orang. Tahap pertama yang dilakukan adalah pengenalan alat dan bahan yang digunakan, kemudian dilanjutkan dengan sesi praktik pembuatannya.

Pelatihan-pelatihan yang telah diterapkan kepada masyarakat menimbulkan dampak-dampak positif diantaranya masyarakat dapat menambah wawasan dan mengetahui tentang bahan-bahan yang digunakan dalam Pembuatan Sabun Cair Cuci Piring dan Proses Membatik Jumput, Masyarakat dapat memahami kegunaan dari bahanbahan yang digunakan dalam Pembuatan Sabun Cair Cuci Piring dan Proses Membatik Jumput, Masyarakat mendapatkan manfaat dan dapat menggunakan produk yang dihasilkan dan diberikan langsung setelah Pembuatan Sabun Cair Cuci Piring dan Proses Membatik Jumput, dan Masyarakat dapat menerapkan ilmu yang didapat untuk dijadikan sebagai ide kewirausahaan.

Masyarakat harus terdorong untuk dapat membuka usaha-usaha baru baik dengan merintis sendiri, dengan keluarga, atau bekerjasama antara satu dengan yang lainnya dalam bentuk usaha yang kecil maupun yang besar

\section{SIMPULAN}

Kegiatan pelatihan dan pembuatan sabun air cuci piring dan batik jumput di Dusun Demangan berjalan dengan baik dan lancar. Warga peserta sangat antusias dan berperan aktif selama proses pelatihan dilakukan. 


\section{DAFTAR PUSTAKA}

Amalia, R. et al. (2018) 'Produksi Sabun Cuci Piring Sebagai Upaya Peningkatkan Efektivitas Dan Peluang Wirausaha', Metana, 14(1), pp. 15-18.

Harahap, E. F. (2012) 'Pemberdayaan Masyarakat Dalam Bidang Ekonomi Untuk Mewujudkan Ekonomi Nasional Yang Tangguh Dan Mandiri', Jurnal Manajemen dan Kewirausahaan, 3(2), pp. 78-96.

Jonnius, J. (2013) 'Menumbuhkembangkan Budaya Kewirausahaan dalam Masyarakat', Menara, 12(1), pp. 48-55.

Malik, A. and Mulyono, S. E. (2017) 'Pengembangan Kewirausahaan Berbasis Potensi Lokal melalui Pemberdayaan Masyarakat', Journal of Nonformal Education and Community Empowerment, 1(1), pp. 87-101.

Melicher, R. L. (2015) Entrepreunerial Finance. Washington: Spatial Technology Inc.

Ningsih, R. (2001) 'Mengenal Batik Jumputan’. Yogyakarta: Adicita Karya Nusa.

Saragih, R. (2017) ‘A Membangun Usaha Kreatif, Inovatif dan Bermanfaat Melalui Penerapan Kewirausahaan Sosial', Jurnal Keiwrausahaan, 3(2), pp. 26-34. Available at: http://jklmii.org.

Sukidjo (2012) 'Peran Pendidikan Kewirausahaan Dalam Pemberdayaan Masyarakat Miskin di Indonesia', Jurnal Economia, 8(1), pp. 33-41.

\section{UCAPAN TERIMAKASIH}

Terima kasih diucapkan kepada:

1. Universitas Ahmad Dahlan sebagai penyumbang dana sehingga kegiatan pengabdian kepada masyarakat ini dapat berjalan dengan lancar dan baik.

2. Pemerintah Kecamatan Gondokusuman dan Warga RW 5 Demangan Gondokusuman yang terlah memberikan dukungan dan bantuan selama proses pelaksanaan kegiatan pengabdian kepada masyarakat. 
2018 Jurnal Pemberdayaan: Publikasi Hasil Pengabdian kepada Masyarakat - ISSN: 2088 4559; e-ISSN: 